\title{
Iraqi science faces lonely road to recovery
}

\section{Declan Butler}

Iraq's beleaguered universities took their first tentative steps towards revival last week by electing interim leaders. But so far the institutions have received precious few offers of outside help in repairing the destruction they suffered at the hands of looters.

Rebuilding Iraq's science, technology and academic base, already weakened by years of economic sanctions, will be a huge task. Looters ransacked and burned parts of Baghdad and Basra universities, stripping them of everything from computers and pipettes to chairs and doors. Similar events occurred at other Baghdad institutions, including Iraq's National Library, which housed more than 500,000 books, and the Al-Awqaf library, home to some 6,000 Islamic manuscripts.

With sanctions against Iraq now lifted, and oil revenue available to pay for reconstruction, these institutions could, in theory, be rebuilt. But officials such as Sami al-Mudhaffar, the biochemist elected last week as acting president of Baghdad University, do not seem to have received any substantial offer of help.

An official at the US Department of Defense's Office for Reconstruction and Humanitarian Assistance, which is overseeing the rebuilding of much of Iraq's infrastructure, says that the office's educational focus will be on "primary and secondary schools, rather than universities". The United Nations Educational, Scientific and Cultural

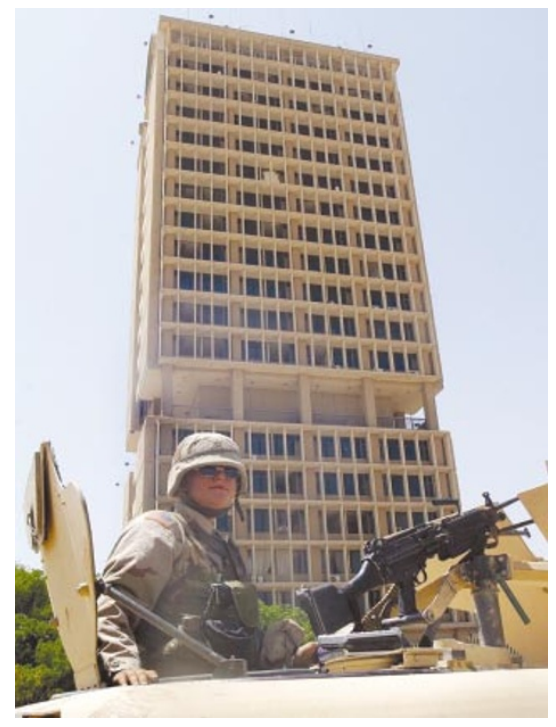

Building for the future? US troops guarded Iraqi universities during their leadership elections.

Organization (UNESCO) last week pledged to help to rebuild Iraq's cultural and educational institutions, but made no specific mention of science. And officials at the European Commission gave no details of any plan to help Iraq's scientific bodies.

Smaller bodies are currently focusing on assessing the extent of the damage before deciding what action to take. The Blue
Shield, a counterpart of the Red Cross that aims to protect libraries, archives and cultural heritage in times of war and natural disaster, is posting information on damage on its website.

And Henry Wright, an archaeologist at the University of Michigan in Ann Arbor, is due to return this week from a fact-finding mission in Iraq for the US National Academy of Sciences. "We are trying to figure out what we can do to help rebuild their universities and scientific communities," says Bruce Alberts, the academy's president.

If reconstruction funds are channelled towards universities, other groups will be able to provide outside support. The Health InterNetwork, a joint venture between the United Nations and publishers that is aimed at making electronic medical journals available to scientists in developing nations for free or at reduced prices, is discussing the rapid inclusion of Iraq in the scheme.

The US National Science Foundation operates an established scheme for funding research in the Middle East. Osman Shinaishin, the programme's manager, says that he began to receive proposals from US researchers for scientific and engineering projects with Iraqi scientists even before the war ended. "If a proposal reaches me it will go through a technical-merit assessment, and will then be funded as long as travel is safe," Shinaishin says.

\section{Anthropologists cast doubt on human DNA evidence}

\section{Alison Abbott, Munich}

When Giorgio Bertorelle published his latest findings on ancient mitochondrial DNA earlier this month, he claimed that his work added yet more weight to the idea that modern humans evolved independently of Neanderthals. But his paper may have a different significance - experts say that the techniques involved, which are also used by other groups, are dogged by problems so fundamental that they can never be used to draw conclusions about the evolution of modern humans.

Bertorelle, based at the University of Ferrara in Italy, claimed to have extracted mitochondrial DNA, which evolves independently of chromosomal DNA, from the bones of Cro-Magnons, Homo sapiens from around 25,000 years ago. The extracted sequences are strikingly similar to modern human DNA, and are very different from those of Neanderthal specimens

(D. Caramelli et al. Proc. Natl Acad. Sci.

USA 100, 6593-6597; 2003).

But experts question whether Bertorelle, and others who are attempting similar experiments, can rule out contamination with material from modern humans. "CroMagnon DNA is so similar to modern human DNA that there is no way to say whether what has been seen is real," says Svante Pääbo, a director at the Max Planck Institute for Evolutionary Anthropology in Leipzig, Germany.

Alan Cooper, an evolutionary anthropologist at the University of Oxford, UK, published the accepted standards of contamination avoidance in 2000 (A. Cooper and H. N. Poinar Science 289, 1139; 2000). He has deliberately contaminated teeth and bones with viral DNA by soaking them in liquid containing the virus. Cooper says that not even extreme decontamination methods, such as application of acid or bleach, can eradicate such DNA completely.

Bertorelle agrees that it is impossible to rule out contamination, but says he used all of the standard precautions in his study.

"We repeated the procedure on a bone from a horse taken from the same layer of the site as the human bones came from," he says. This bone yielded only horse DNA, he notes, whereas it would also have yielded human DNA if contamination had been a problem.

But such controls cannot definitively rule out contamination of the Cro-Magnon sample. Researchers such as Pääbo and Cooper see no way to resolve the issue, and are now increasingly questioning the value of studies such as Bertorelle's. "We know that contamination is almost impossible to avoid," laments Cooper.

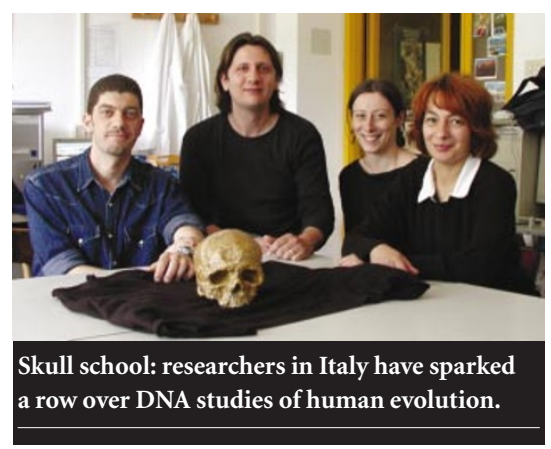

